\title{
OPTIMATION OF FIRE EXTINGUISHMENT SYSTEMS IN X STATION CENTER OF CRUDE OIL AND GAS STORAGE
}

\author{
Amiral Aziz', ${ }^{1,2}$ Andre Nugroho² \\ ${ }^{1}$ National Laboratory for Energy Conversion Technology \\ Agency for the Assessment and Application of Technology \\ ${ }^{2}$ Department of Mechanical Engineering National Institute of Science and Technology \\ e-mail : amiral.aziz@bppt.go.id
}

\begin{abstract}
This paper discusses some research results that were carried out to optimize the fire extinguishment system of $X$ Station in South Sumatera. To optimize the fire extinguishing system at station $\mathrm{X}$, a system modification has been done, which included: changes in the number of stockpile tank units, changes in capacity and dimensions of oil tanks, and changes in fire wall construction. With the change in capacity and dimensions, especially the storage tank unit, it is necessary to recalculate whether the water demand in the fire protection system is still sufficient according to the existing system condition. From this research, it can be concluded that the maximum flow rate of foam under the existing condition is $1631.6 \mathrm{gpm}$ while the optimum condition is $65 \%$ smaller than the existing system condition at $570.54 \mathrm{gpm}$. The cooling water flow rate of $615.09 \mathrm{gpm}$ at optimum condition is lower than the existing system conditions of $1409.33 \mathrm{gpm}$. The required water to the fire extinguishment system is $250 \mathrm{gpm}$; this value is smaller than the existing system capacity of $2074 \mathrm{gpm}$. By using performance curves of Grundfos Data Booklet, for the capacity of pump $1250 \mathrm{gpm}$, the total head pump and pump efficiency are obtained $103.48 \mathrm{~m}$ and $77.5 \%$, respectively.
\end{abstract}

Keywords: optimation; tank; water; foam; pump

\section{INTRODUCTION}

Fires in industrial and manufacturing plants have great potential for significant economic and financial loss to both the industrial plant and the community. Recovery from an industrial fire includes not only replacement of equipment and facilities at higher costs but also temporary and permanently lost business income, loss of skilled employees during the time the plant is closed, loss of profits on damaged finished goods, and extra expenses to restore operations[1]. One of the industries that are at high risk of fire, explosion, and leakage of hazardous and toxic materials, environmental pollution, and production failure is the industry for processing crude oil. The improper storage, handling, and use of flammable and combustible liquids have been the cause of many deaths, injuries, and disastrous fires[2], [3]. The assessment of fire safety protection of industrial technology was carried out by Kamila Kempna et al[4]. They evaluated specific hazards and possible impact including possible damages to human health, property or environment with considered type of technology.

The analysis of 985 fire incidents related to oil- and gas production on the Norwegian continental shelf was carried out by Sesseng et al[5] They concluded that even though many incidents are reported, the large majority of these have not imposed risks for severe fire accidents. Twenty-nine percent of the incidents were false alarms, which must be regarded as a high number in an industry where any production stop could be extremely costly.

Apart from human error, equipment damage and natural factors such as lightning strikes are the main triggers for fires. The design of the unit process placement, the installation of a barrier wall, lightning arrester, or lightning catcher is one of the active protection that has been carried out at station $X$. The flash point at station $X$ is located at the dumping tank and the skimming pit, so that the fire protection system is more focused on that area. 
To optimize the fire extinguishing system at station X, a system modification has been done, which included: changes in the number of stockpile tank units, changes in capacity and dimensions of oil tanks, and changes in fire wall construction.

This paper discusses some research results that were carried out to optimize the fire extinguishment system of $X$ Station in South Sumatera so that the optimal capacity (Q) of water and foam is obtained according to the layout conditions after optimation.

\section{MATERIALS AND METHODS}

Description of the Object of Research of the Piping System in the Fire Water System

This research was conducted at Station $X$ in South Sumatra. Figure 1 shows the process of fire water flow station $X$ before optimation (existing)[6]. This system has stockpile tank units, and a skimming pit with capacity be seen in Table 1 . The total capacity of the stockpile tank is 19,000 bbls. The fire protection system uses two units of operating pumps and 1 unit of standby with a capacity of $1500 \mathrm{gpm}$ per unit[6].

\section{Flow Diagram of Study}

The diagram of study methods and data processing optimation planning for fire protection systems in this research can be seen in Figure 2. Calculation of the surface area of firewalls and tanks are based on the dimensional data in the layout and as-built drawings of the tank respevtively. There are four fire zones, namely zones $A, B, C$, and $D$, in the system before optimation[6]. The area of each zone and its units can be calculated using a simple formula, including:

a. Area of a circle $\left(\pi \times r^{2}\right)$, this formula is used to get the area of the liquid pool tank, which is circular.

b. Tube blanket area $(\pi \times D \times h)$ This formula is used to find the surface area of the cover of the tank/tube.

c. The area (length $x$ width) of this formula is used to get the fire wall area and skimming pit.

The layout of the system after optimation changes in tank size and capacity, as can be seen in Figure 3 and Table 2. The total capacity of the stockpile tank is 20,000 bbls. The fire protection system still uses the previous system, using two operating pumps and one standby with a capacity of $1500 \mathrm{gpm}$ per unit with a head of 150 psi.

Optimation planning is carried out by utilizing the addition of a fire wall and the use of the internal foam method, which refers to the NFPA 11 table B1 standard for all tanks[7]. The use of internal foam will significantly reduce the area to be protected. In Figure 3, it can be seen that the process of planning to use internal foam in each tank. This makes it possible to produce foam only on certain internal tanks so that it will become more efficient in the amount of water use and foam concentrate. The capacity of the storage after optimation is given in Table 2.

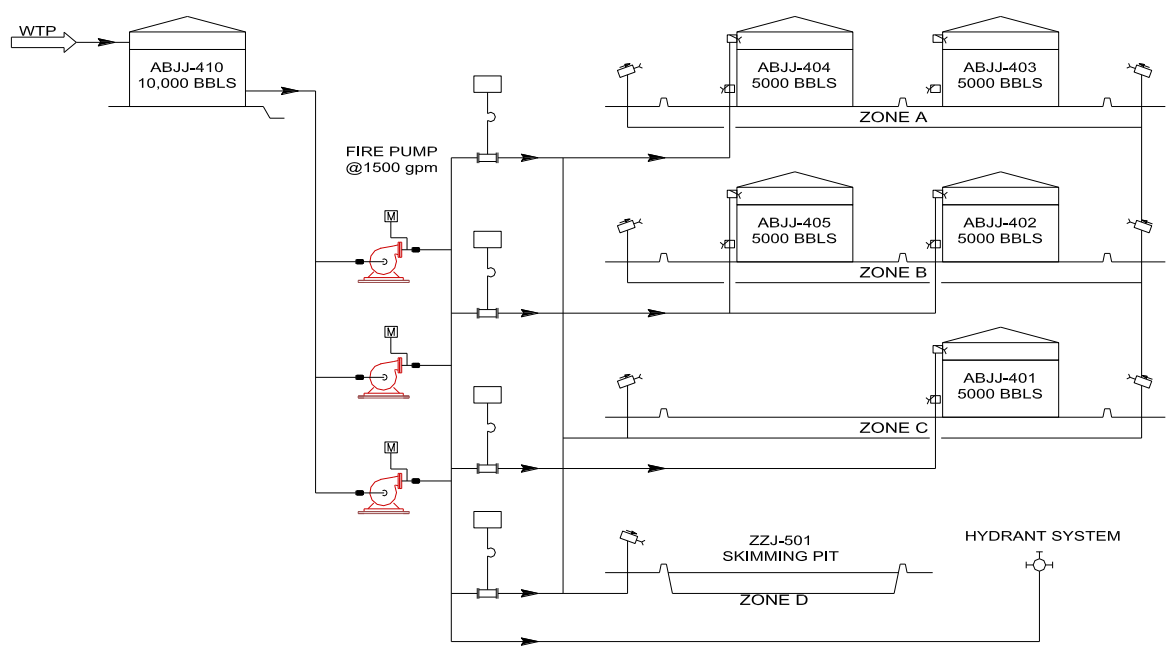

Figure 1. Flow fire water process before optimation [6] 
Table 1. The capacity of stockpile tanks and oil tanks [6]

\begin{tabular}{llc}
\hline No & $\begin{array}{c}\text { The name of the } \\
\text { equipment }\end{array}$ & Capacity (bbls) \\
\hline 1 & Storage Tank ABJJ-401 & 3000 \\
2 & Storage Tank ABJJ-402 & 3000 \\
3 & Storage Tank ABJJ-403 & 5000 \\
4 & Storage Tank ABJJ-404 & 5000 \\
5 & Storage Tank ABJJ-405 & 3000 \\
6 & Skimming Pit ZZZJ-501 & 1292 \\
\hline
\end{tabular}

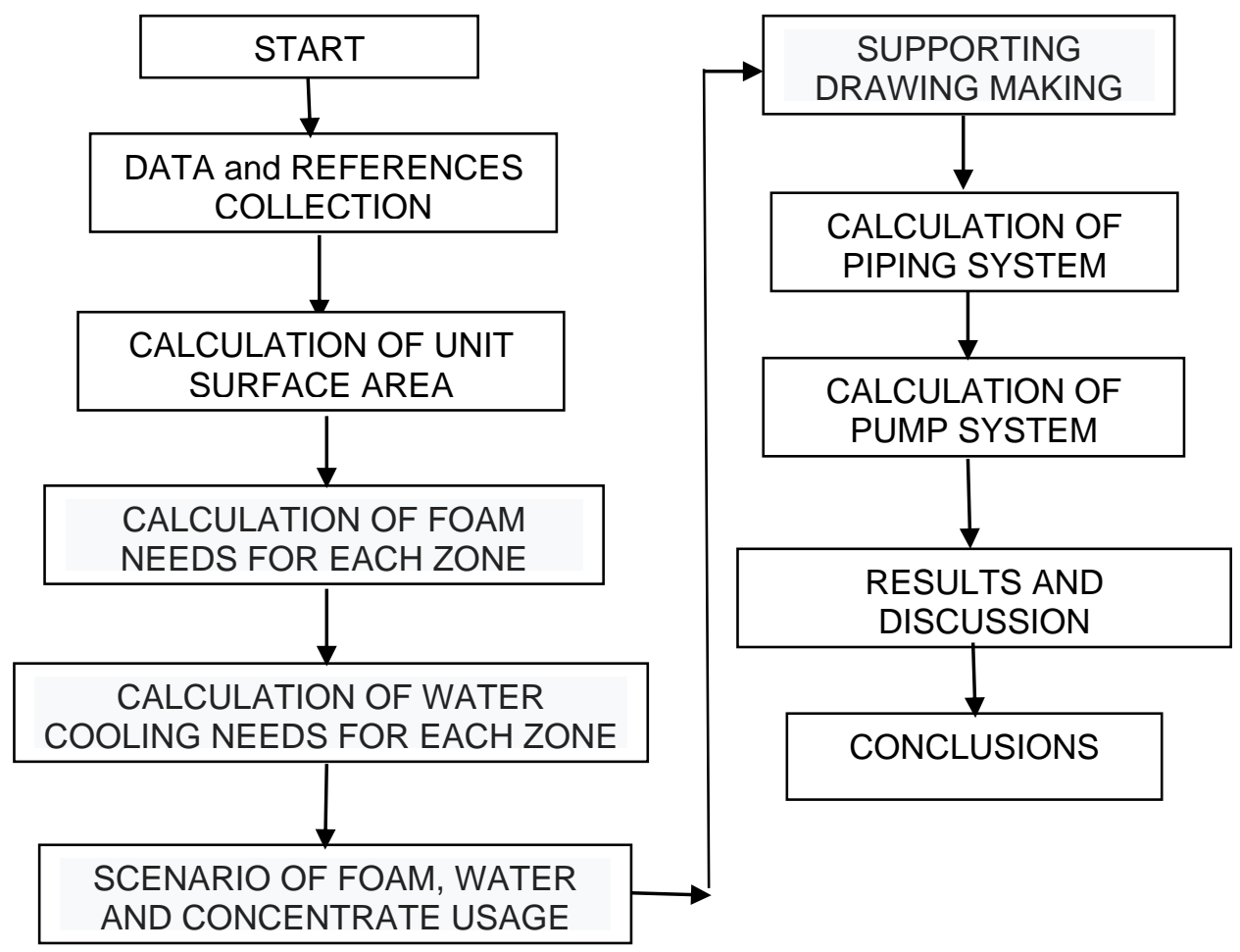

Figure 2. Flow chart of the study method

The need for cooling water and foam (foam) for fire protection.

The chemical chain reaction between the fuel, heat, and oxygen represents the fourth component of the fire equation[1], [2]. They are fuel, heat, oxygen and chemical reaction. Anytime something burns, these four components are present. Preventing the combination of these elements will prevent a fire. If one of the elements is removed from the fire situation, the fire will be extinguished [1]. The most common extinguishing method is to remove the heat. This is usually done with water[1].

The need for cooling water and foam flow rates for fire protection in each zone at oil and gas production stations can be seen in Table 3 and Table 4 . The foam system is applied to stockpile tanks or in an open location where flammable liquids are present. Foam has a function as a fire triangle breaker. The duration for foaming is 55 minutes for internal and 30 minutes for external / outside the holding tank.

\section{Fire Zone}

Fire zones are the areas within the installation where equipment is grouped by nature and/or homogeneous level of risk attached to them[8]. The main purpose of creating a fire zone is to make a location isolated from other zones in the event of a 
fire at a certain location. This is necessary so that the calculation of the availability of water and foam is sufficient to overcome fire in the zone that requires the largest discharge $Q$ ). These zones are grouped based on process units that have the same process tendency and hazard. Figure 4 shows the outline of the zoning for facilities[8].

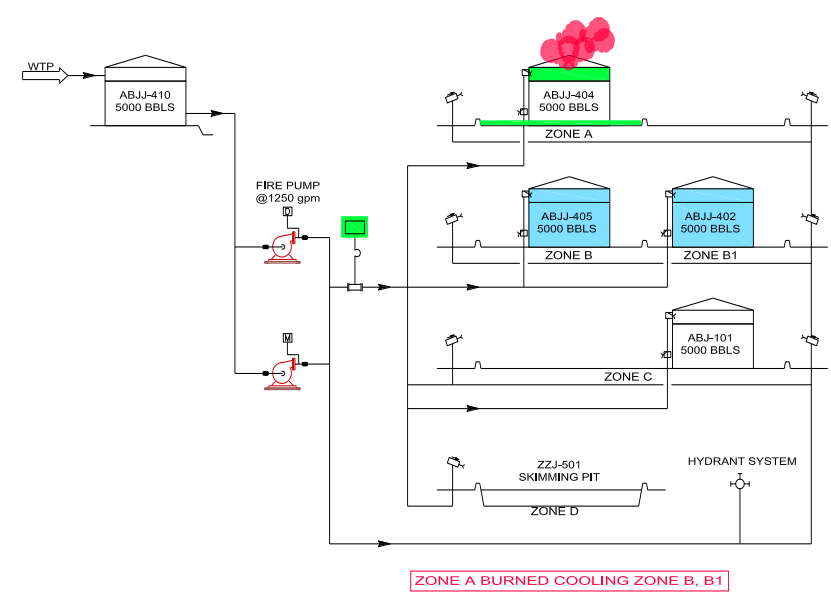

Figure 3. Process of flow fire water after optimation

Table 2. Storage tank capacity after optimation

\begin{tabular}{lcc}
\hline No & Equipment & Capacity (bbls) \\
\hline 1 & Water Injection Tank ABJ-101 & 5000 \\
2 & Storage Tank ABJJ-402 & 5000 \\
3 & Storage Tank ABJJ-404 & 5000 \\
4 & Storage Tank ABJJ-405 & 5000 \\
5 & Skimming Pit ZZZJ-501 & 1292 \\
\hline
\end{tabular}

Data source: Results of studied calculation.

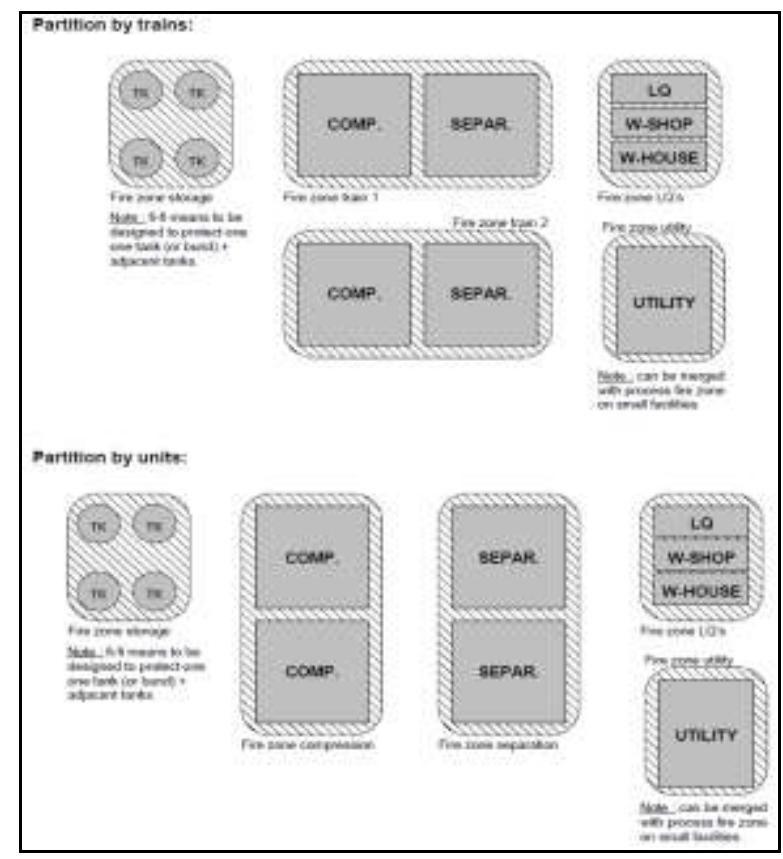

Figure 4. Zone Division Based on Project and Units Stage [9] 
Table 3. Cooling water spray rate application [10]

\begin{tabular}{ccccc}
\hline No & Equipment & \multicolumn{2}{c}{ Application of flow rate } & Location \\
\hline 1 & Atmospheric Tank & $\begin{array}{c}0.1 \\
\left(\mathrm{Gpm} / \mathrm{ft}^{2}\right)\end{array}$ & $\begin{array}{c}4.1 \\
\left(\mathrm{Gpm} / \mathrm{m}^{2}\right)\end{array}$ & Roof and sides \\
\hline
\end{tabular}

Data source: API RP 2030[10]

Table 4. Application of flow rate of foam in areas of fire protection walls [7]

\begin{tabular}{ccccc}
\hline No & Equipment & \multicolumn{2}{c}{ Application of flow rate } & Location \\
\hline \multirow{2}{*}{1} & Atmospheric Tank & 0.1 & 4.07 & Liquid Surface \\
& inside/outside & $\mathrm{Gpm} / \mathrm{ft}^{2}$ & $\left(\mathrm{Lpm} / \mathrm{m}^{2}\right)$ & \\
2 & Low level foam & 0.1 & 4.07 & Liquid Surface \\
\hline
\end{tabular}

Data source: NFPA 11[7]

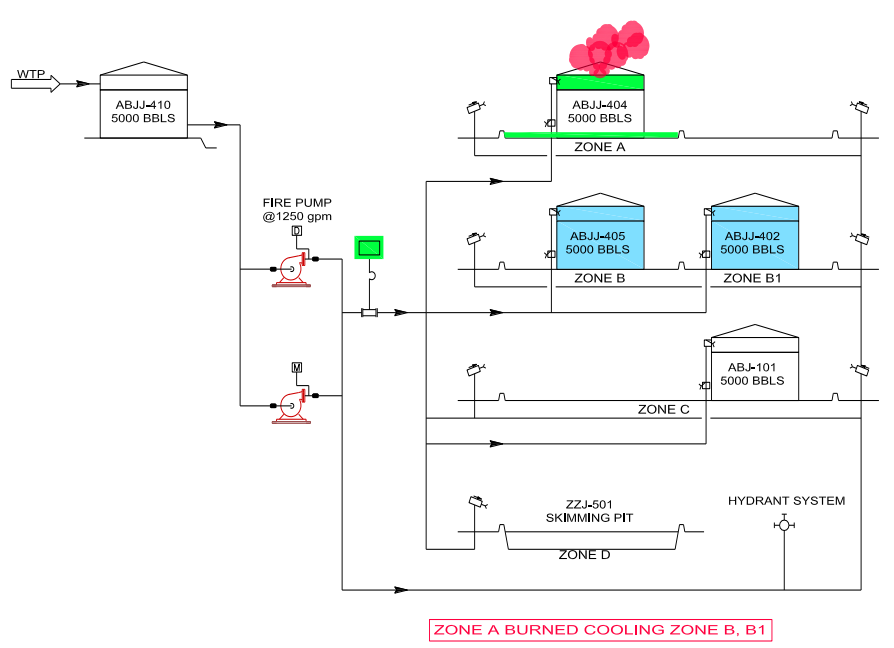

Figure 5. Scenario Zone A burns in conditions after optimation

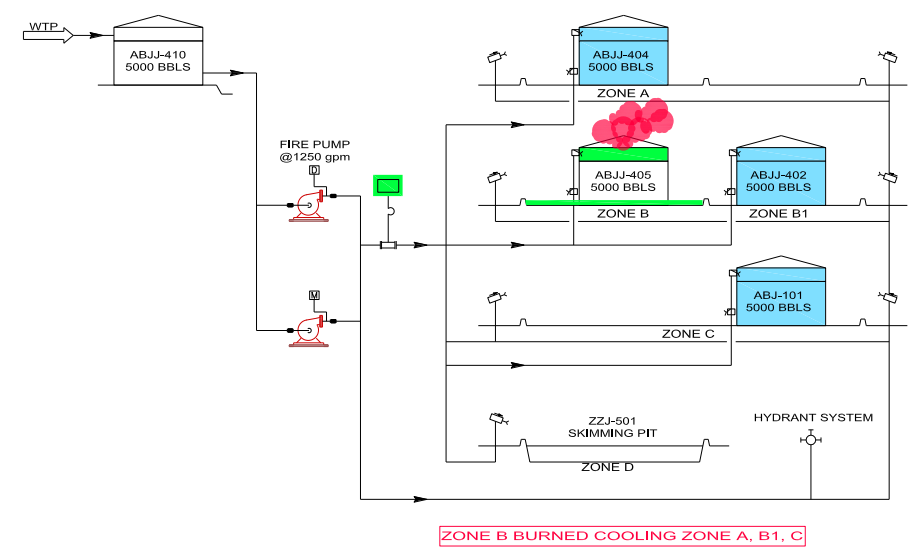

Figure 6. Scenario Zone B burns in conditions after optimation 
M.I.P.I Vol.15, No 1, April 2021 - (16-27)

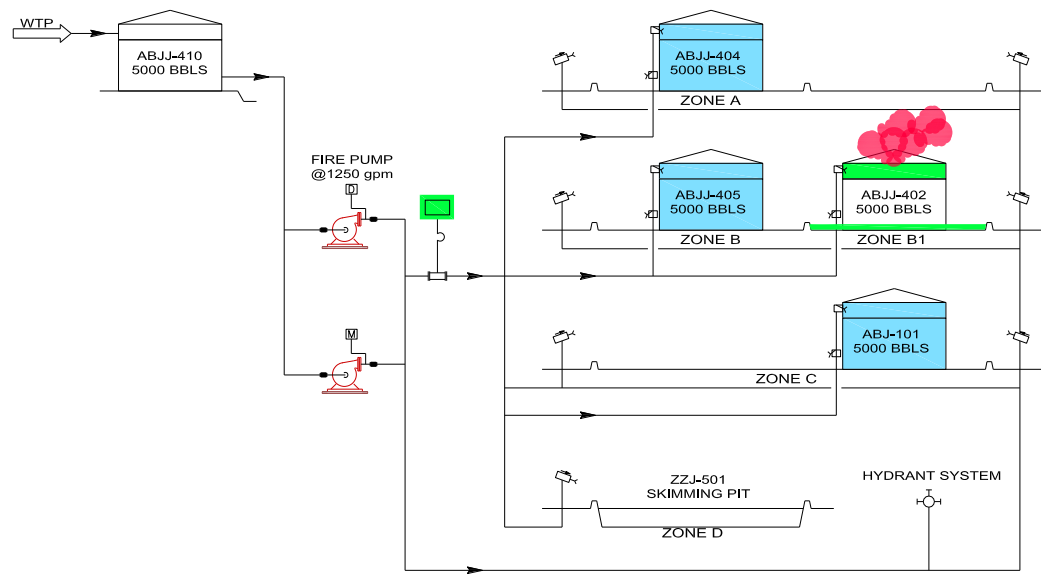

ZONE B1 BURNED COOLING ZONE A, B, C

Figure 7. Scenario Zone B1 burns in conditions after optimation

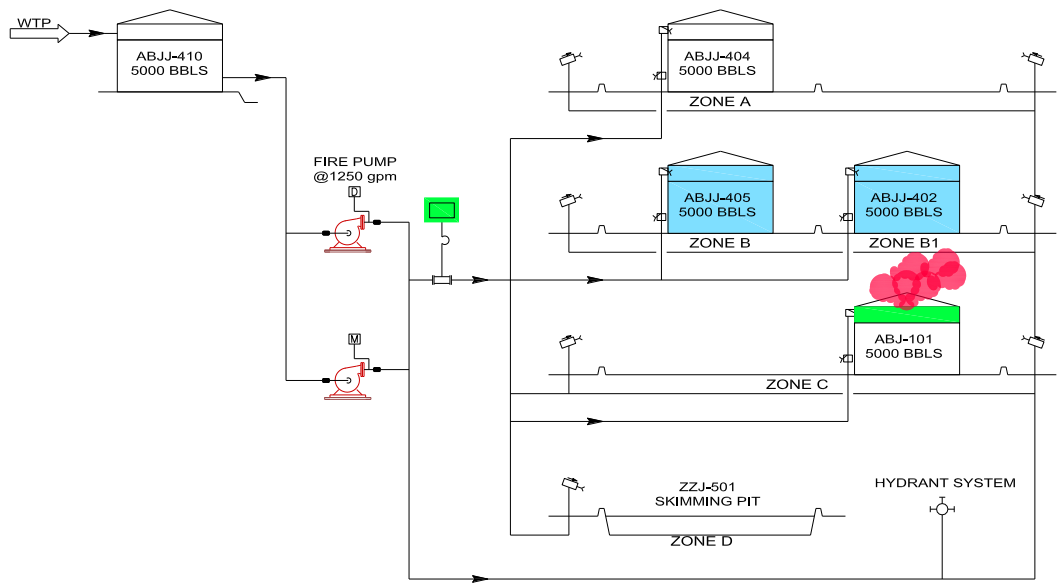

ZONE C BURNED COOLING ZONE B, B-1

Figure 8. Scenario Zone $C$ burns in conditions after optimation

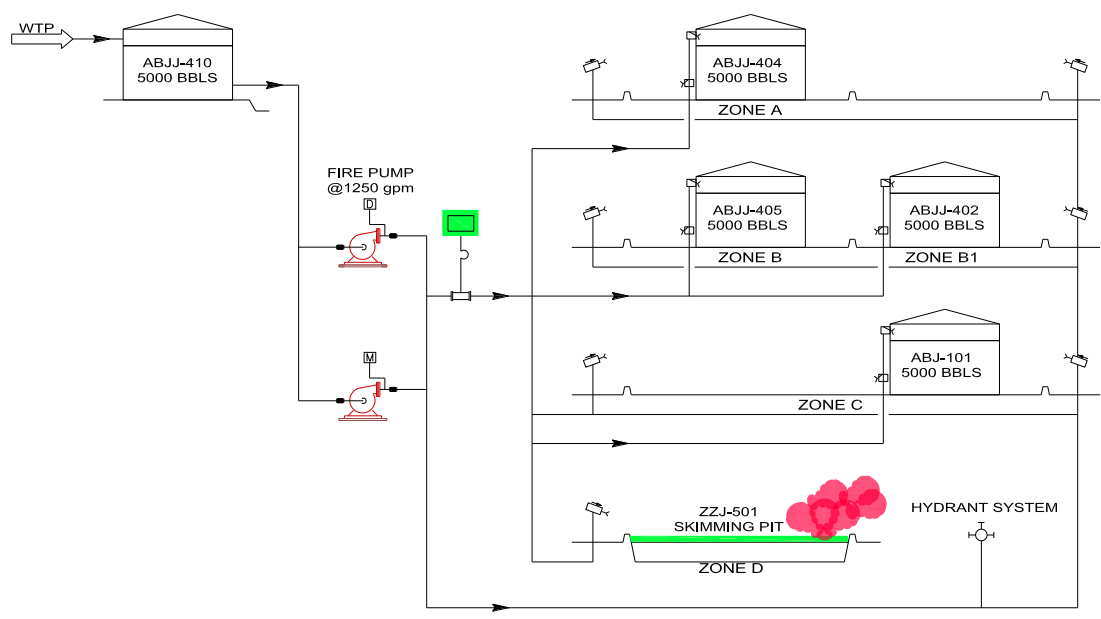

ZONE D BURNED FOAMING ZONE D

Figure 9. Scenario Zone D burns in conditions after optimation 


\section{Fire Scenario Design}

The design of a fire scenario in the system after optimation can be seen in Figures 5 to 9 . From Figure $\mathbf{5}$, it can be seen that if zone $A$ is burning, cooling is carried out in zones $B$ and $B 1$. Cooling is carried out in zones $\mathrm{A}, \mathrm{B} 1$, and $\mathrm{C}$ if there is a fire in zone $B$, as shown in Figure 6. Likewise, if a fire occurs in zone B1, cooling is carried out in zones $A, B$, and $C$, as shown in Figure 7. If zone $C$ burns, cooling is carried out in zones B and B1, as shown in Figure 8. From Figure 9, it can be seen that if a fire occurs in zone $\mathrm{D}$, foaming is carried out in zone D.

\section{Pump Performance Parameters}

There are four components that must be combined to determine the total head $(\mathrm{H})$ of the system. They are static head, friction head, pressure head and velocity head.[11], [12] . The total head is written as follows[11], [12]

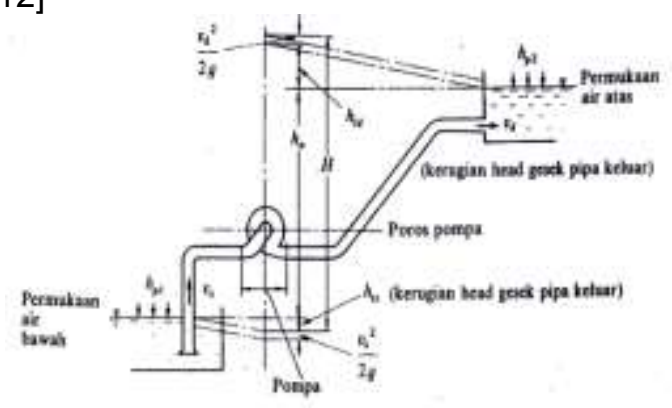

Figure.10. Pump Head[11]

$$
H=h_{a}+\Delta h_{p}+h_{l}+\frac{v_{d}^{2}}{2 g}
$$

Where:

$$
\begin{array}{ll}
\mathrm{H} & \text { : total head }(m) \\
\mathrm{h}_{\mathrm{a}} & \text { : total static head }(\mathrm{m})
\end{array}
$$

Static head is the total elevation change that a liquid must undergo. Static head is normally measured from the surface of the liquid in the supply vessel to the surface of the liquid in the delivery vessel or location. The positive sign (+) is used if the water level on the discharge is higher than the suction:

$$
\Delta h_{p}=h_{p 1}-h_{p 2}
$$

hl :Various head losses in pipes,valves, bends, joints and others (m)[11], [12], [13], [14]

$v^{2} / g \quad$ : velocity Head $(m)$

g : gravitation $\left(=9,81 \mathrm{~m} / \mathrm{s}^{2}\right)$

\section{Pump Power}

The power required to drive the pump can be calculated using the equation[11], [12].

$$
\begin{array}{ll}
P_{\text {Pompa }} & =\frac{Q \times H \times \rho \times g}{\eta_{\text {Pompa }}} \ldots \ldots \ldots \ldots \\
Q & : \text { water debit }\left(\mathrm{m}^{3} / \mathrm{dt}\right) \\
\mathrm{H} & : \text { total head }(\mathrm{m}) \\
\mathrm{g} & : \text { gravitation }\left(\mathrm{m} / \mathrm{s}^{2}\right) \\
\rho & : \text { density }\left(\mathrm{kg} / \mathrm{m}^{3}\right) \\
\eta_{\text {pompa }} & : \text { pump efficiency. }
\end{array}
$$

\section{RESULTS AND DISCUSSION Unit Surface Area}

The area of zones $A, B, C$, and $D$ in the existing and after optimation is given in Table 5 and Table 6, and Figure 11. From Figure 11 , it can be seen that the surface area of the existing stockpile tank is $17039 \mathrm{ft}^{2}$ where this area is $4 \%$ larger than the area for after optimation of 16402 . $\mathrm{ft}^{2}$. The ABJJ-403 tank has been demolished due to damage with age so that the surface area decreases after optimation. The external pool area after optimation increased by $3 \%$ from $23786 \mathrm{ft}^{2}$ to $24474 \mathrm{ft}^{2}$. After optimation, the tank capacity was increased from 3000 bbls to 5000 bbls so that the internal pool area increased by 4 percent from $5900 \mathrm{ft} 2$ to $6164 \mathrm{ft}^{2}$.

Calculation of foam, water, and concentrate requirements

Foam extinguishing systems have been used extensively in the petrochemical industry for the extinguishment of flammable liquid fires[1], [15]. For Low Expansion Foam Extinguishing Systems have been regulated in the NFPA 11 standard[1], [7]. While the cooling water capacity requirements in each zone are regulated by API RP 2030 standard[3]. Water is the primary agent for cooling equipment, structures, and tank shells exposed to a fire. Water works well because it has a large capacity for absorbing heat[6].

Figure 12 shows the comparison of foam, water, and concentrate usage before and after optimation. The maximum flow rate of foam in the existing condition is 1631.6 $\mathrm{gpm}$, while in the optimum condition, it is $65 \%$ smaller than the existing condition, which is $570.54 \mathrm{gpm}$. The cooling water flow rate in the optimation condition is $615.09 \mathrm{gpm}$ lower than the existing condition, which is $1409.33 \mathrm{gpm}$. The ratio of concentrate to foam is $97 \%$ water and $3 \%$ concentrate, respectively. The use of concentrate is 
directly proportional to the use of foam so that concentrate efficiency is achieved up to $65 \%$.

\section{Comparative Analysis With Scenarios}

From Figure 13 it can be seen a comparison of the scenario of using foam in each zone in the existing conditions and after optimation. The fire scenario will show a more detailed comparison of which zones the use of foam or water reaches the highest value. The foam flow rate in zone $A$ decreased significantly from $1632 \mathrm{gpm}$ in the existing conditions and $571 \mathrm{gpm}$ in the optimation conditions. The same thing has a significant decrease in zones B and B1 from $1355 \mathrm{gpm}$ in the existing conditions to 452 $\mathrm{gpm}$ in the optimal conditions. The significant decrease that occurred in zones $A, B$, and $B 1$, apart from the use of internal foaming, was also due to the addition of embankments. In zone $\mathrm{C}$, the reduction in foam usage reaches $89 \%$ due to a change in the function of the tank to water injection so that no external foaming is needed.

The cooling water requirements in each zone are shown in Figure 14. $410 \mathrm{gpm}$ of water is required in zone $A$ and $C$ under optimation conditions. This value is lower than the existing condition of $589 \mathrm{gpm}$. The water requirement in zones $\mathrm{B}$ and $\mathrm{B} 1$ in the optimation conditions is $615 \mathrm{gpm}$, which is lower than the existing conditions of 1409 $\mathrm{gpm}$. The total water required will determine the pump capacity that complies with the NFPA 20 standard[9]. The required tank capacity must be able to serve the length of time of blackout (240 minutes) that has been regulated by API 2001. For foam tanks with NFPA 11 , the blackout time (55 minutes for internal and 30 minutes for external).

Table 5. The surface area before optimation

\begin{tabular}{lccccc}
\hline \multicolumn{1}{c}{ Section } & Unit & Zona A & Zona B & Zona C & Zona D \\
\hline Firewall Area & $\mathrm{ft}^{2}$ & $10,459.56$ & $9,044.03$ & $8,708.27$ & \\
Total Vessel Surface area & $\mathrm{ft}^{2}$ & $8,201.15$ & $5,892.16$ & $2,946.08$ & \\
Total Internal Fire Pool Area & $\mathrm{ft}^{2}$ & $2,344.72$ & $1,387.33$ & 693.67 & $1,474.65$ \\
Total External Fire Pool Area & $\mathrm{ft}^{2}$ & $8,114.84$ & $7,656.70$ & $8,014.60$ & \\
\hline
\end{tabular}

Data source: Results of studied calculation.

Table 6. The surface area after optimation

\begin{tabular}{lcccccc}
\hline \multicolumn{1}{c}{ Section } & Unit & Zona A & Zona B & Zona B1 & Zona C & Zona D \\
\hline Firewall Area & $\mathrm{ft}^{2}$ & $5,705.35$ & $4,522.01$ & $4,522.01$ & $8,708.27$ & \\
Total Vessel Surface area & $\mathrm{ft}^{2}$ & $4,100.57$ & $4,100.57$ & $4,100.57$ & $4,100.57$ & \\
Total Internal Fire Pool Area & $\mathrm{ft}^{2}$ & $1,172.36$ & $1,172.36$ & $1,172.36$ & $1,172.36$ & $1,474.65$ \\
Total External Fire Pool Area & $\mathrm{ft}^{2}$ & $4,532.99$ & $3,349.65$ & $3,349.65$ & $7,535.91$ & \\
\hline
\end{tabular}

Data source: Results of studied calculation.

Table 7. Desain before optimation

\begin{tabular}{lccccc}
\hline \multicolumn{1}{c}{ Section } & Unit & Foam & $\begin{array}{l}\text { Water } \\
\text { Cooling }\end{array}$ & Total Water & Concentrate \\
\hline $\begin{array}{l}\text { If Zone A burned, cooling for } \\
\text { zone B }\end{array}$ & gpm & 1631.60 & 589.22 & 2171.87 & 48.95 \\
\hline $\begin{array}{l}\text { If Zone B burned, cooling for } \\
\text { zone A, C }\end{array}$ & gpm & 1354.89 & 1409.33 & 2723.57 & 40.65 \\
\hline $\begin{array}{l}\text { If Zone C burned, cooling for } \\
\text { zone B }\end{array}$ & gpm & 1096.07 & 589.22 & 1652.40 & 32.88 \\
\hline $\begin{array}{l}\text { If Zone D burned, foaming for } \\
\text { zone D }\end{array}$ & gpm & 147.47 & 0.00 & 143.04 & 4.42 \\
\hline Maximum of the Scenarios & gpm & $\mathbf{1 6 3 1 . 6 0}$ & $\mathbf{1 4 0 9 . 3 3}$ & $\mathbf{2 7 2 3 . 5 7}$ & 48.95 \\
\hline
\end{tabular}

Data source: Results of studied calculation. 
Table 8. Design after optimation

\begin{tabular}{lccccc}
\hline \multicolumn{1}{c}{ Section } & Unit & Foam & $\begin{array}{l}\text { Water } \\
\text { Cooling }\end{array}$ & Total Water & Concentrate \\
\hline $\begin{array}{l}\text { If Zone A burned, cooling for } \\
\text { zone B }\end{array}$ & gpm & 570.54 & 410.06 & 963.48 & 17.12 \\
\hline $\begin{array}{l}\text { If Zone B burned, cooling for } \\
\text { zone A, C }\end{array}$ & gpm & 452.20 & 615.09 & 1053.72 & 13.57 \\
\hline $\begin{array}{l}\text { If Zone C burned, cooling for } \\
\text { zone B }\end{array}$ & gpm & 452.20 & 615.09 & 1053.72 & 13.57 \\
\hline $\begin{array}{l}\text { If Zone D burned, foaming for } \\
\text { zone D }\end{array}$ & gpm & 117.24 & 410.06 & 523.78 & 3.52 \\
\hline $\begin{array}{l}\text { Maximum of the Scenarios } \\
\text { gpm }\end{array}$ & $\mathbf{5 7 0 . 5 4}$ & $\mathbf{6 1 5 . 0 9}$ & $\mathbf{1 0 5 3 . 7 2}$ & $\mathbf{1 7 . 1 2}$ \\
\hline
\end{tabular}

Data source: Results of studied calculation.

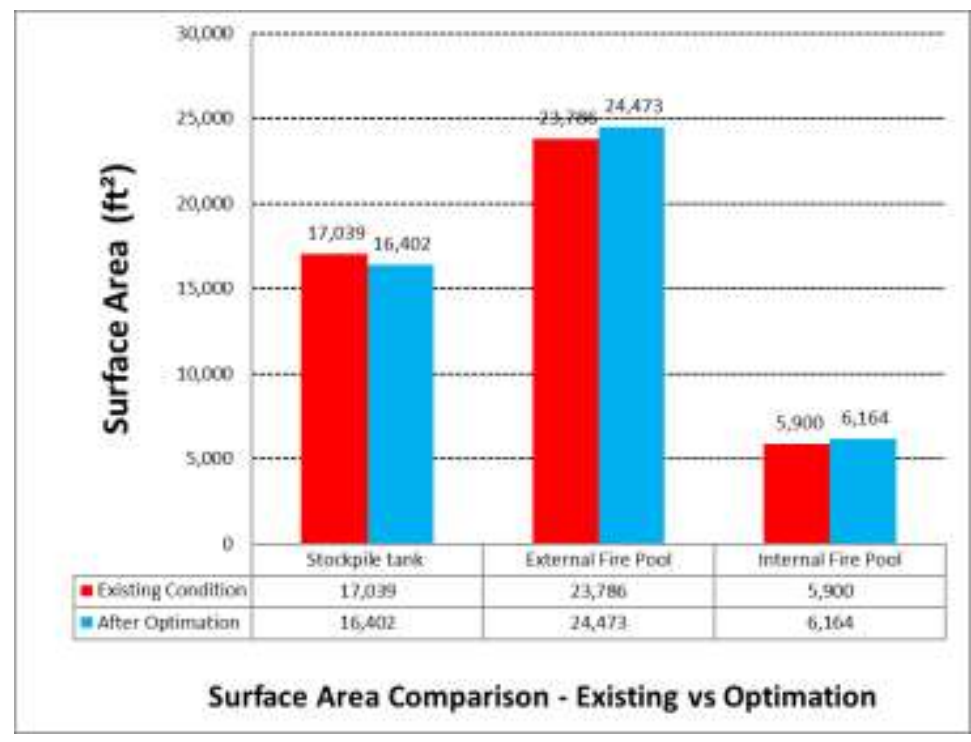

Figure 11. Surface area comparison - Existing versus Optimation

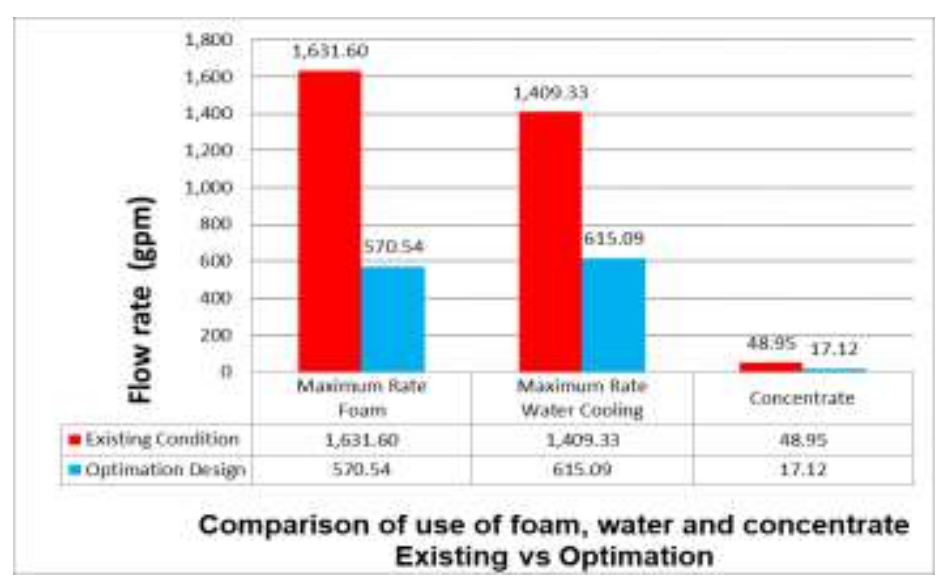

Figure 12. Comparison of the use of foam, water, and concentrate at Existing vs. Optimation 


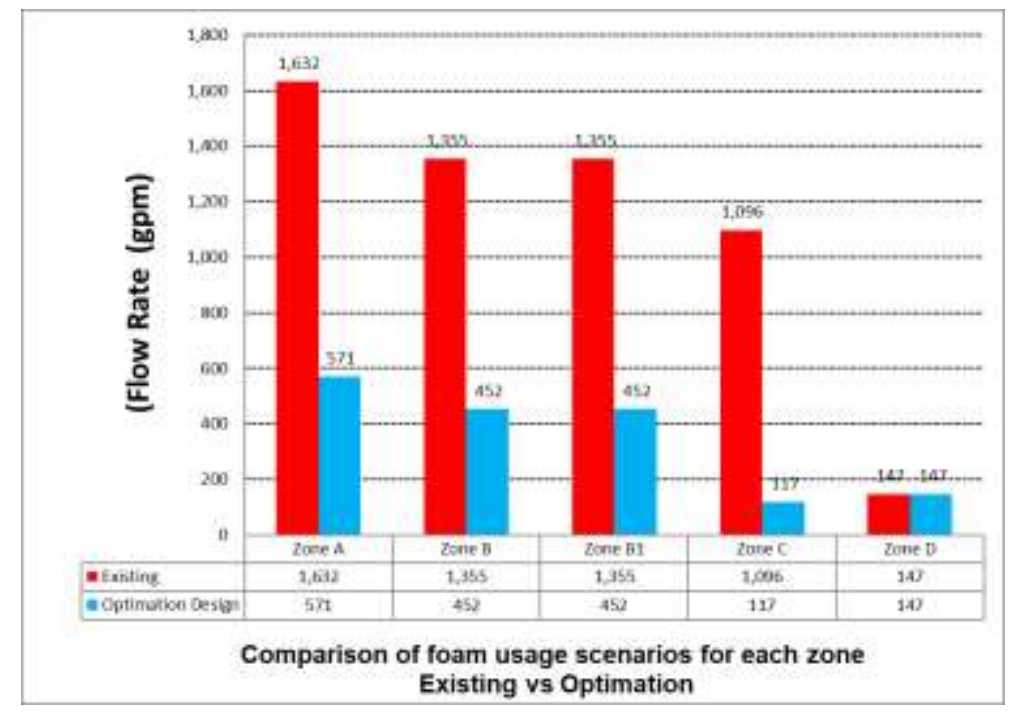

Figure 13. Comparison of foam usage scenarios for each zone Existing vs. optimation

\section{Piping and Pump System Analysis.}

From Table 7 and $\mathbf{8}$, it can be seen that the total water required by the fire extinguishing system is based on a fire scenario. In the existing condition, the maximum total water required occurs when zone $\mathrm{B}$ is burning, where zones $\mathrm{A}$ and $\mathrm{C}$ must be cooled with the total water required of $2733.57 \mathrm{gpm}$. Meanwhile, after optimation, the maximum total flow rate of water needed is $1053.72 \mathrm{gpm}$, namely when Zone B or Zone $\mathrm{C}$ is burning. Based on the total required water flow rate of $1053.72 \mathrm{gpm}$, taking into account the volumetric efficiency and other losses of the pump, a pump with a capacity of $1250 \mathrm{gpm}$ is selected.

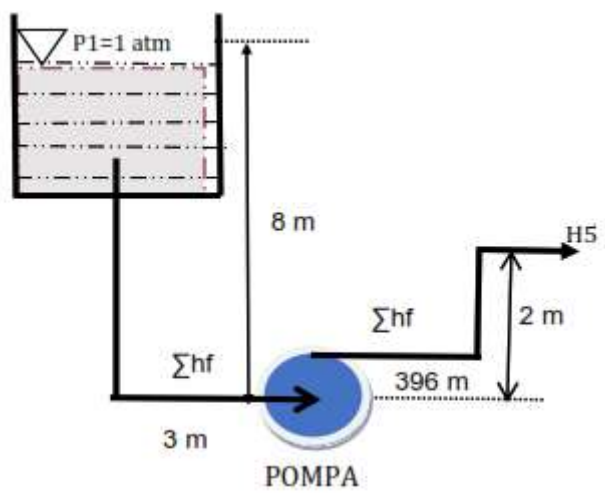

Figure 14. Schematic of a fire extinguisher piping system

Figure 14 shows a schematic of a fire extinguisher piping system at station $X$. On the suction side, there is a pipe with a total length of $3 \mathrm{~m}$ and a discharge pipe with a total length of $396 \mathrm{~m}$. From the calculation results obtained, major losses and minor losses on the suction side are $0.25 \mathrm{~m}$ and $0.21 \mathrm{~m}, \quad$ respectively[11], [13], [14]. Meanwhile, on the discharge side, major losses and minor losses were $9.61 \mathrm{~m}$ and $3.72 \mathrm{~m}$, respectively[11], [12], [13], [14]. The total losses that occurred were $13.79 \mathrm{~m}$. In this fire extinguishing system pipe design, the pressure at the farthest point of the pipe at point $\mathrm{H} 5$ has been limited to the company standard MEP-F-ES-001, which is 150 psi. = $1034213.55 \mathrm{~Pa}$., while the pressure on the suction tank $=1 \mathrm{~atm}=101325 \mathrm{~Pa}$. From the calculation, it is obtained that the water velocity out of the press pipe $=2.04 \mathrm{~m} / \mathrm{s}[11]$, [13], [14].

Using Bernoulli's equation, the water pressure at the pump discharge can be calculated as follows[11], [12], [13], [14].

$\left(p_{\text {Nozzle }}-p_{H 5}\right)=\rho \times g \times \Delta Z+\left(h_{f}\right)_{\text {discharge }}$

$=996 \times 9,81 \times 2+9,61+3,72=19554,85 \mathrm{~Pa}$ $=2,84 p s i$

$p_{\text {Noszle }}=p_{H 5}+2,84=150+2,84$ $=152,84 \mathrm{psi}$

So the minimum pressure at the pump discharge (nozzle) is 152.84 psi in order to meet the pressure at the farthest point $\mathrm{H} 5$ of 150 psi.

Figure 15 with $Q=1250 \mathrm{gpm}$ and a pump head of $103.48 \mathrm{~m}$, an impeller with a size of 267 is used. From figures $\mathbf{1 6}$ and $\mathbf{1 7}$ with a 267 impeller and a capacity of $Q=$ $1250 \mathrm{gpm}$, the input power (Pi) and pump efficiency are obtained $90 \mathrm{~kW}$ and $77.5 \%$, respectively. 


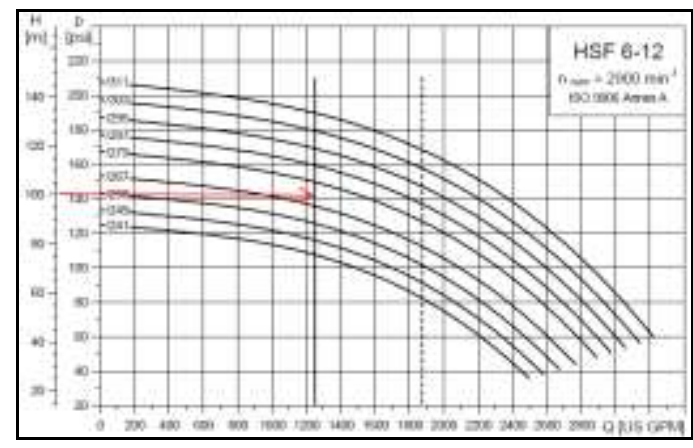

Figure 15. Performance Curve Head and Q[16]

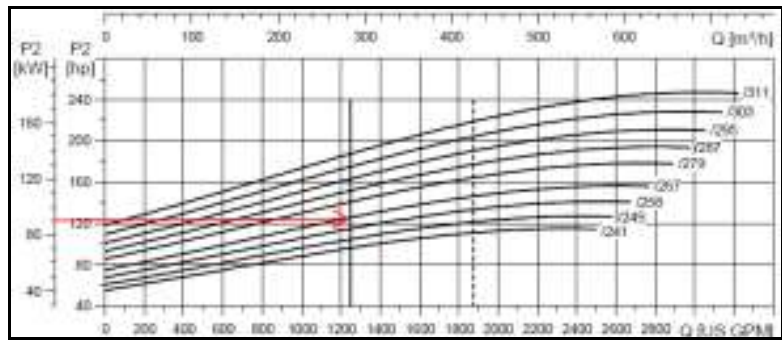

Figure 16. Performance Curve P2 and Q[[16]]

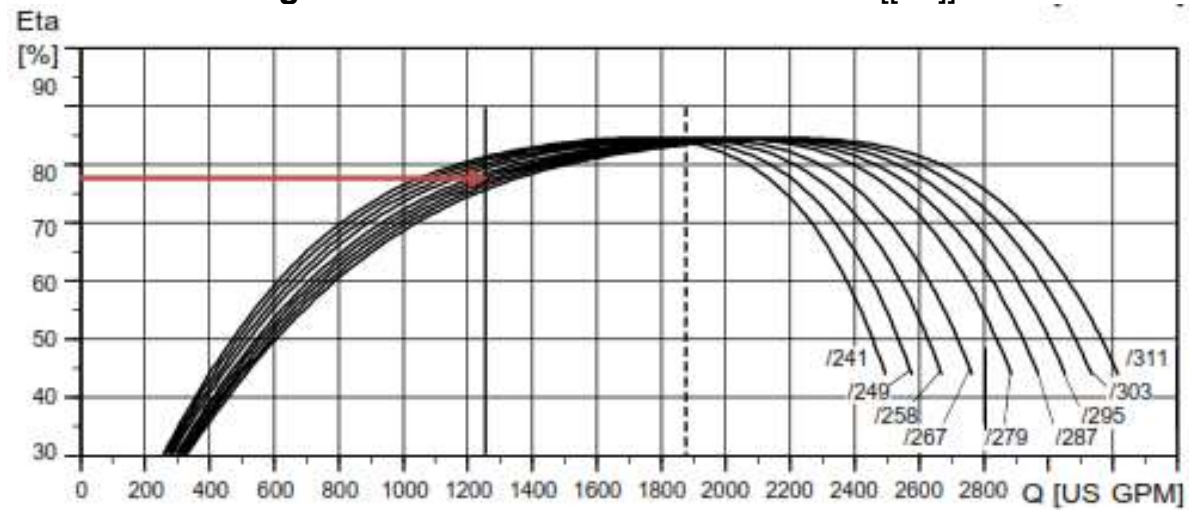

Figure 17. Performance Curve Efficiency and Q[[16]]

\section{CONCLUSION}

From the results of the research, it can be concluded that:

a. The maximum flow rate of foam under existing condition is $1631.6 \mathrm{gpm}$, while the optimum condition is $65 \%$ smaller than the existing system condition at $570.54 \mathrm{gpm}$.

b. The cooling water flow rate of 615.09 gpm at optimum condition is lower than the existing system conditions of 1409.33 gpm.

c. The required water for the fire extinguishment system is $250 \mathrm{gpm}$. This value is smaller than the existing system capacity of $2074 \mathrm{gpm}$. d. By using performance curves of Grundfos Data Booklet, for the capacity of pump $1250 \mathrm{gpm}$, the total head pump and pump efficiency are obtained 103.48 $\mathrm{m}$ and $77.5 \%$, respectively.

e. The addition of bundwall between tanks is very effective in reducing the need for water and foam.

\section{AUTHOR INFORMATION}

Corresponding Authors

Email: amiralaziz58@gmail.com

Phone: +62 81212239900

\section{Author Contributions}

First Author and Second Author have contributed equally to this work. 


\section{ACKNOWLEDGEMENTS}

The author would like to thank the management of South Sumatra Station $X$ for their permission and assistance so that this research can be carried out.

\section{REFERENCES}

[1] Casey C. Grant, P.E. Chapter 4.9 Fire Protection and Prevention, Standard Handbook of Plant Engineering third Edition pp 4169-4221, The McGrawHill Companies, 2008.

[2] Bery Romadhon, Fire Protection Analysis On Gas Production Company and Power plant, the Indonesian Journal of Occupational Safety and Health, November 2018.

[3] Yi Zhoua, Yang Du, Xiaogang Zhao, Peili Zhang, Sheng Qi, Experimental Study on the Explosion of Gasoline-air Mixture in Reduced-scale Storage Tank, The Open Petroleum Engineering Journal, Volume 12, 2019.

[4] Kamila Kempna, Jan Smolka, Milos Kvarcak, Ivan Kricfalusi, Zdenek Stejskal, Tomaz Hozjan and Dionysis Kolaitis, Fire Safety Protection Assessment of Industrial Technologies, Journal of Physics: Conference Series, 2018.

[5] Sesseng.C, Storesund.K, SteenHansen.A, Analysis of 985 fire incidents related to oil- and gas production on the Norwegian continental shelf, Conference: Safety and Reliability - Safe Societies in a Changing World, ESREL Conference, At: Trondheim, Norway, 2018

[6] Station X, Detail Design Fire Water System of $X$ Station - South Sumatera.
[7] NFPA 11, Standard for Low, Medium and High Expansion Foam, 2016

[8] M. Massoud, GS EP SAF 253, Impact Area, Restricted area and Fire Zone, Total E\&P

[9] NFPA 20, Standard for the Installation of Stationary Pumps for Fire Protection, 2019.

[10] API RP 2030, Application of Fixed Water Spray Systems for Fire Protection in Petroleum Industry, Fourth Edition 2014.

[11] Akhmad Muji Hartono and Amiral Aziz, Evaluation of the Centrifugal Pump Efficiency at the Cilincing Distribution Water Treatment Unit., Enerlink- Jurnal Energi dan Lingkungan, Vol. 14 No. 1, Juni 2018.

[12] Johann Friedrich Gülich, Centrifugal Pumps, Second Edition, SpringerVerlag Berlin Heidelberg, 2010

[13] J. Phillip Ellenberger, Piping And Pipeline Calculations Manual, Construction, Design, Fabrication, and Examination, Jurnal and Book, Science Direct. Second Edition 2014.

[14] Robert W. Fox, Alan T. McDonald, Philip J. Pritchard, John W. Mitchell. Fluid Mechanics, 9th Edition SI Version ,Wiley, 2016

[15] Dennis Nolan, Handbook of Fire and Explosion Protection Engineering Principles for Oil, Gas, Chemical, and Related Facilities 4th Edition, Elsevier Book and Journal, 16th October 2018.

[16] Grundfos, Fire DNF - Fire HSF Grundfos Fire Systems, Grundfos Data Booklet, 2017. 